\title{
On the Fine Structure of the Amphioxus Photoreceptor
}

\author{
By \\ Taisuke Nakao \\ Anatomical Laboratory of Prof. R. Ura, Tohoku University \\ School of Medicine, Sendai
}

(Received for publication, February 15, 1964)

\begin{abstract}
Amphioxus photoreceptors were investigated with electron microscope. The visual cell of the Becherauge has the Stiftchensaum as the photoreceptoral structure which is composed of microvilli of the visual cell surface. Immediately underlying the Stiftchensaum is the tubular zone which is formed by the welldeveloped endoplasmic reticulum. Clumps of mitochondrial aggregations are found just inside of this zone, and numerous glycogen granules in the basal part of the cell.

The fine structures of other photoreceptoral organs (dorsal cells, ependymal sense cells and infundibular organ) were elucidated and discussed.
\end{abstract}

It is now a well established fact that in a number of animals that have eyes, the light sensitive substances, visual pigments, are located within visual cells. In some eyes such substances have been proved not to be dispersed throughout the cytoplasm but to be concentrated in specially differentiated metaplasmic bodies of the visual cells ${ }^{2}$.

Our knowledge of photoreceptor structures has been brought together by many recent investigations with electron microscope which have succeeded remarkably well in showing them clearly in many animals. Complexity and differences of structural details of photoreceptors in many animals may suggest their diversity or complexity in the mechanism of photoreceptor activity.

The Amphioxus photoreceptor has long been a good material for investigation, because of its phylogenetic position in the scheme of visual development. It is desirable to obtain at higher resolution additional structural informations on its visual components. As photosensitive organs of Amphioxus there have been described the Pigmentfleck ${ }^{2}$, the Dorsalzellen ${ }^{3)}$, and the Becheraugen ${ }^{4}$.

In the present study the Amphioxus photoreceptors and the infundibular organ have been investigated with electron microscope.

\section{MATERIAL AND METHODS}

Branchiostoma belcheri cut transversely about $1 \mathrm{~mm}$ thick in the fixative was used for this study. The fresh solutions of 1 per cent osmium tetroxide in

中尾泰右 
isotonic veronal-acetate buffer $\left(\mathrm{pH} 7.4\right.$ ) according to Caulfield ${ }^{5)}$, were used to the whole Amphioxus and then for immersion of small segments at a temperature of 1 to $4^{\circ} \mathrm{C}$ for 1 to 2 hours. After dehydration by passage through a graded series of ethanol (50 per cent to absolute alcohol by increments of 10 per cent), the specimens were embedded in Epon ${ }^{6}$.

The sections were cut with a Portor-Blum microtome, mounted on celloidincoated grids, stained according to the method of Reynolds) and then examined with a HITACHI electron microscope type HS-6.

In order to follow better the progress of sectioning, thick sections were cut along with the thin, mounted on glass slides, stained with toluidine blue ${ }^{8)}$ and examined to determine the part of the block in which photoreceptors were located and from which thin sections should be cut, and further to know its relations with the neighbouring organs. The block was then trimmed with the razor under a binocular microscope to be freed of other parts of no interest to this study.

Other specimens, especially serial sections prepared by Prof. Ura by fixing with 10 per cent neutral formalin, embedding in celloidin and staining with hematoxylin-eosin, were used for investigation.

\section{OBSERVATION}

\section{Becheraugen}

Many observations ${ }^{9,10}$ ) on the pigment flecks which locate in the spinal cord of Amphioxus along its central canal had been made till Hesse elucidated its contour in detail and called them 'Becheraugen'4). Hesse described their distribution in the spinal cord as the following: transversely they locate on each side of the central canal and ventral to it, and longitudinally they distribute forming numerous groups arranged in series, each of which seems to bear relation to the myotome respectively. Yamada ${ }^{11)}$ indicated that each of groups is composed of two smaller groups. They appear at the level of the third myotome. This first group consists of two Becheraugen on each side. From the level of the fourth myotome they increase in number upto 25 on each side. From the middle of the spinal cord they decrease more and more in number. Yamada reported that Amphioxus of $50 \mathrm{~mm}$ in length has 1,500 Becheraugen on each side.

Especially it is noteworthy that the segments of the right side are shifted rearwards just a half of one segment against those of the left side, and corresponding to it the groups of the Becheraugen on the right side are shifted rearwards by the same length against those on the left side.

Moreover, both the Becheraugen situated ventral to the central canal and those on its right side look ventrally, and those on the left side look dorsally. According to Hesse ${ }^{4}$, all or most of Becheraugen look the right side slightly to be oriented to the coming light wave from the right as a whole. 
It is a further distinguishing feature that this photoreceptor organ, Becherauge, is composed of two cells, a pigment and a visual cell, and is ensheathed by processes, probably of the ependymal cells which contain bundles of filamentous structures.

1) Visual cell under light microscope

The visual cell, about 13 microns in diameter, has a clear, round or oval nucleus with a round nucleolus. The most characteristic feature of the cell is the particular structure, little-pin border or Stiftchensaum ${ }^{2,4}$, which is found along the contour of the visual cell of many lower animals ${ }^{12}$. In the Becheraugen of Amphioxus such a structure is found at the apical surface of the visual cell, adjacent to the pigment cell, and has a faintly striated appearance when viewed under the light microscope. Immediately underlying the Stiftchensaum is found the granular layer. Boeke ${ }^{13}$ ) and Joseph ${ }^{3}$ proved networks of neurofibrils in the cytoplasm. A process which Hesse regarded as a neurite, arising from the basal part of the cell, has an irregular course which one rarely sees more than a short segment. The pattern of its neural connections has not yet been determined.

2) Visual cell under electron microscope

In the electron micrograph it is clearly shown that the Becheraugen are ensheathed or encapsuled by ependymal cells or by their processes (Fig. 1). At the apical cell surface adjacent to the pigment cell a particular structure is noticed and at the other parts the visual cell lacks prominent structures (Fig. 3). From the findings in electron micrographs the author concludes that the Stiftchensaum is composed of numerous microvilli arising from the visual cell's border.

This conclusion is obtained from the following evidence. Fig. 1 gives an impression that the peripheral part of the Stiftchensaum is composed of short and small tubular compartments bearing an appearance of undeveloped microvilli or of rod, while the central part is composed of tightly packed tubular compartments which are long and large, bearing an appearance of well-developed microvilli (Fig. 3).

Some micrographs show clearly that the peripheral part of the Stiftchensaum is composed of small and short microvilli. In these micrographs it is easy to trace their contours completely because they are less tightly packed than those of the central part (Figs. 1, 2 and 4).

Then it is confirmed that the tubular compartments of the central part of the Stiftchensaum are also microvilli of the visual cell. In micrographs of the radial section at lower magnification, at the zone of attachment to the visual cell membrane the Stiftchensaum shows a scalloped outline, through which a clear demarcation line of the visual cell membrane is discernible (Fig. 1).

The examination at higher magnification has shown that the walls of the tubular compartments which are represented as dense osmiophilic boundary 
lines or membranes of about $100 \mathrm{~A}$ in thickness, are apparently continuous with this demarcation line of the visual cell membrane, and at the other end they appear to be tapered, closed or rounded off, which proves that the tubular compartments of the central part are microvilli of the visual cell (Fig. 3). These microvilli (0.63 to $0.83 \mu$ in length, 0.12 to $0.2 \mu$ in diameter at the base), are tightly packed with a uniform interspace of $25 \mathrm{~m} \mu$, with their long axes normal to the contour of the visual cell. Therefore they are arranged radially along the cell border, not in parallel, as a whole.

In the tangential section the individual microvilli show their annular or hexagonal profils of variable diameters, bounded by a uniform osmiophilic layer of about $100 \mathrm{~A}$ in thickness, which are identical with those described above in the longitudinal section. Although these microvilli appear irregularly contoured both in the longitudinal sections and in the cross, which is supposed to be due to the numerous artefact sources, annular profils of variable diameters are thought to be due to the different levels of the tapering tubular units, through which the plane of section has passed. In certain preparations tightly packed microvilli of the central part of the Stiftchensaum contain irregularly shaped microvesicular structures of variable sizes (Fig. 3), while those of the peripheral part have homogeneously dense contents, thus bearing a rod-like appearance (Fig. 4). The walls of adjacent microvilli are not cemented together by the particular intermediate substance as in the case of the rhabdomeres of some lower animals, as referred to.

Just inside the Stiftchensaum lie two prominent structures (Figs. 1 and 3). Immediately underlying the Stiftchensaum there is a tubular zone which is composed of tightly packed tubular compartments. These compartments are bordered by agranular membranes and oriented for most of their length in a direction normal to the cell border, bearing an appearance of annular profils when crossed (Fig. 6). It is a notable feature that this zone is strictly confined to the area of the Stiftchensaum or closely associated with it (Figs. 1 and 2).

One might expect that the walls of the tubular compartments are directly continuous with those of the microvilli of the Stiftchensaum; these compartments are formed by the infoldings of the visual cell membrane. Additional findings as the following, however, make it unlikely.

At the peripheral part of the Stiftchensaum rod-like microvilli are less tightly packed than those of the central part, where the tubular compartments underlying it are well-developed. There the wall of the rod-like microvilli bears no evidence of direct continuation of the tubular structures of the zone. In any preparation such a direct continuation between them has not yet been proved to exist.

In the electron micrographs at higher magnification the walls of the tubular compartments have been shown to possess a thickness of about 80 to $90 \mathrm{~A}$. 
It should be noted that adjacent to the tubular zone clumps of mitochondria of various size and shape are observed to be interposed among the well-developed agranular membranes which are tightly packed and irregularly arranged (Figs. 3 and 5). The direct continuation of the walls of the tubular compartments of the zone with these well-developed membranes are often observed. These membranes are clearly shown to be the endoplasmic reticulum by the existence of RNP granules on their surface (Figs. 3 and 5). This fact supplies the critical evidence to show that these membranes are endoplasmic reticulums and that the tubular zone is formed by specially differentiated endoplasmic reticulum, not by the infoldings of the surface membrane as described by Eakin and Westfall17).

Some mitochondria contain homogeneously dense inclusions bounded by a uniform membrane (Fig. 4). Dispersed among these mitochondria and membranes are found granular and agranular vesicles of variable size and shape, small aggregations of free RNP granules and neurofilament-like structures. In the distal or apical part of the cell is found the well-developed Golgi complex. It envelops an axial fibril which extends towards the cell surface (Figs. 1 and 2).

Close examination of the axial fibril at higher magnification revealed that it is composed of banded filaments which closely resemble kinetodesmal fibrils or rootlets of flagella or cilia found in other tissues of Amphioxus (e.g. epithelium of the gill arch and of the intestine, ependymal cell). The periodicity of $600 \mathrm{~A}$ is

consistent with those generally common to the rootlets of cilia or flagella of Amphioxus.

The nucleus, irregularly oval in shape, is located in the basal part of the cell (Fig. 4). In the triple layered nuclear membrane there have been observed nuclear pores. The nucleoplasm is composed of fine granular materials distributed at random and contains a round nucleolus. In the basal part of the cell and the process, neurite, are found abundant granules which are distributed in the form of clusters or rosettes (Figs. 1,2,4,5 and 6). These fine granules are assumed to be glycogen on the basis of electron microscope observations of other investigators ${ }^{14,15)}$. Some dense bodies of unknown character are scattered. Mitochondria, granular or agranular vesicles, small aggregations of free RNP granules and other organelles are dispersed more in the apical part of the cell rather than in the basal part.

The visual cell is separated from the pigment cell by a narrow intercellular space which is mostly occupied by the microvilli of the Stiftchensaum. Because the microvilli are absent at a certain area of the peripheral part of the Stiftchensaum, there is formed an intercellular cavity, in which a flagellum is occasionally encountered and into which some short microvilli are projected from the pigment cell (Fig. 9). The derivation of the flagellum, the nature of its distal part and its relation to the microvilli have not yet been confirmed. 
Ensheathed together with the visual cell by ependymal processes and closely associated with the visual cell on its side, there is a structure which contains mitochondria and many microvesicles, and the wall of which is thick in a certain place (Fig. 7). Because of its fine structure, it is regarded as the foot-piece or the bouton, the enlarged terminus of an axon. The thick area is similar to the active points in synaptic membranes of other neural connections ${ }^{16)}$.

3) Pigment cell under electron microscope

The pigment cell is concave at one side, wine-cup shaped, and contains a visual cell in its cavity (Figs. 1,2 and 6) ${ }^{4}$. The nucleus is located at the convex side of the pigment cell (Fig. 14). The cytoplasm is clear and organelles are rarely found. The abundance of pigment granules which are variable in size, bounded by a uniform, thin membrane, makes the most characteristic feature of the cell. It should be noted that pigment granules distribute preferentially along the Stiftchensaum, although they are absent in the marginal areas of the cup. Sometimes a pigment cell borders the central canal, as do the ependymal cells (Fig. 8). Two Becheraugen are occasionally seen to be in close contact (Fig. 6).

2. Dorsal cell

Joseph ${ }^{2,3}$ observed particular cells in the spinal cord of Amphioxus which are distinguished by their characteristics in structure. The fine structures of the dorsal cells under light microscope are consistent with those of the Becheraugen except the absence of the caps of the pigment cells. Franz ${ }^{9}$ indicated that they appear at the level of the Stirnbläschen and extend caudally in the dorsal wall of the neural tube till they disappear at the level of the third myotome. These cells are ensheathed individually by the ependymal cell processes, by which they are separated from the another. Under light microscope these cells are characterized by the possession of the Stiftchensaum with a granular layer underlying it ${ }^{2,3}$. Franz described an additional observation that the dorsal cells are also seen in the caudal end of the spinal cord²).

Electron microscope observations revealed that the dorsal cells are ensheathed by some thin layers of the ependymal cell processes, by which they are separated respectively (Fig. 13). It contains generally a round nucleolus and the clear nucleoplasm.

The most notable feature of the dorsal cell is the possession of the Stiftchensaum, the existence of which Franz denied in opposition to Joseph. One- fourth of the cell surface is provided with the Stiftchensaum, as indicated by Eakin and Westfall17).

Micrographs at lower magnification show that it consists of structures with a striated appearance which are assumed to be profils of relatively straight, parallelly packed membranes. The striation of the Stiftchensaum is oriented perpendicularly to the cell contour (Fig. 13). 
In another micrograph at higher magnification it is observed to consist of paired membranes with the uniform interspace of about $27 \mathrm{~m} \mu$. Close investigation of the micrograph revealed that these paired membranes which are remarkably tortuous in their course when sectioned through another plane, however, are extensions of the cell border (Figs. 12 and 13).

An additional finding of a flagellum interposed among the lamellar structures makes it more likely that the Stiftchensaum of the dorsal cell is formed by the lamellar projections of the surface membrane, not by the infoldings. The flagellum is composed of nine peripherally placed filaments and two central filaments enveloped by a uniform membrane and each of the nine outer filaments appears double, consisting of two subfibers. The presence of the banded fibrils (Fig. 11) in the dorsal cell affords us a strong support to the idea that the flagellum found in the Stiftchensaum of the dorsal cell (Fig. 12) belongs to the dorsal cell. The fact that the lamellar structures which lie on the same plane of section together with the flagellum means that these lamellar structures are formed by the projections of the cell surface, because the fine structure of the flagellum shows clearly that the flagellum was crossed at the level of its extracellular part.

From these observations it is speculated that the Stiftchensaum is built up of lamellar projections of the surface membrane which are irregularly folded but oriented with an end perpendicularly to the cell surface.

Further examination shows that tubular units, uniformly sized structures, the contents of which are homogeneously dense, are seen with some of these lamellar projections of the Stiftchensaum (Fig. 13). Moreover, the content of these lamellar projections is not identical with the cytoplasm just inside the Stiftchensaum which are characterized by the presence of abundant vesicles and granules of variable size with variable contents.

Mitochondria are mostly found in the marginal region of the cytoplasm just inside the Stiftchensaum. The well-developed Golgi complex is found near the nucleus. A banded axial fibril with periodicity of $600 \mathrm{~A}$ exists apical to the nucleus extending to the Stiftchensaum (Fig. 11).

In the course of electron microscope investigation of the caudal end of the Amphioxus spinal cord the author found a cell which is locate ventral to the central and canal is identical in the structural features with the dorsal cell mentioned above.

3. Ependymal sense cell

Edinger ${ }^{18)}$ made an observation on the ependyma of the Amphioxus and described ciliated cells with processes projecting into the ventricular cavity and with long stocks which, tapering basally, flare out into trumpet pieces. From the general feature he obtained an impression that it is a sense cell.

Electron microscope observations of the central nervous system of Amphioxus afforded interesting findings. In the cross section of the neural tube at the level of 
the infundibular organ cells with prominent structures were observed in the dorsal wall, interposed among the ependymal elements, Adjacent to the luminal cell surface of these cells are lamellar structures which bear striking resembla* 、 to the outer segments of the rod and cone of the vertebrate eyes (Figs. - id 15).

Although the author has not yet obtained clear critical evid, such as connecting piece, that proves this lamellar structure to has deri from a cilium-like outgrowth of an ependymal cell, it is likely that this lamella ructure and the luminal end of the ependymal sense cell are joined together b, a short connecting piece derived from a flagellum (Fig. 14).

The photoreceptoral, lamellar structure is composed of many doublemembrane discs and vesicles arranged like those of the sense cells in the pneal complexes of some animals ${ }^{19-28}$. At higher magnification the linear arrangeinent of vesicles is evident (Figs. 14 and 15). Although there are good reasons to believe that these vesicles are something more than fixation artefacts ${ }^{29,30,1}$, distortion of the arrangement of discs and formation of viescles in the photoreceptoral structures may be the artefact. Such whorls of membranes and unpatterned disposition of tubules and cisternae have been described in the frontal anc. pineal organs of the frog ${ }^{22,24-26)}$.

The vesicles, the interior of which is clear, are assumed to be formed by fusion of adjacent single membranes of adjacent discs, but to speculate the contrary is not impossible (Fig. 15).

These discs consist of a bordering membrane of 50 to $60 \mathrm{~A}$ in thickness and of the intermediate layer of 200 to $220 \mathrm{~A}$ in thickness. At many points adjacent discs are tightly packed with a uniform extracellular interspace of about $30 \mathrm{~m} \mu$; at others they are separated with variable degrees of interspace.

The discs contain microvesicles of about $200 \mathrm{~A}$ in diameter, the interior of which is homogeneously dense (Fig. 15).

In the distal part of the cell comparable to the inner segment of the cone and rod are found most mitochondria, agranular vesicles of variable size with light content, bundles of fibrils, a pair of centrioles with converging tubules, small aggregations of free RNP granules, granules of variable size with various content limited by a membrane, granular ER and the Golgi complex (Fig. 15).

Only a small amount of cytoplasm with a few organelles is found in the proximal or basal part of the cell.

Some of these sense cells are seen to contain abundant glycogen granules in the basal part of the cell.

\section{DISCUSSION}

\section{Becheraugen,}

Satir, as reported by Miller, ${ }^{1)}$ investigated the Becheraugen of Amphioxus with electron microscope and reported that the Stiftchensaum is composed of micro- 
villi of the visual cell's border and have a honeycomb-like structure. Recently, Eakin and Westfall ${ }^{17}$ ) described that the Stiftchensaum is formed by infoldings of the cell membrane to form a maze of long, irregular tubules, in opposition to the information of Satir, and that the distal part of these tubules is an undulating tubule of elatively uniform bore $(10 \mathrm{~m} \mu)$, whereas the proximal segment is frequent swollen.

In 2 present study it has been proved that the Stiftchensaum is composed of tightly packed microvilli of the visual cell. The author supposes that the distal segment described in their report corresponds to the intermicrovillus space described in the present study and the proximal to the tubular compartment undérlying the microvilli respectively. As the author has mentioned previously, the walls of the microvilli have not yet been observed to be continuous with th walls of the latter. In the micrographs of Eakin and Westfall the direct continuation of the distal segment with the proximal one is not demonstrated anywhere. For these reasons the author dares to say that their description is incorrect in this respect.

The existence of intracellular filamentous structures arouses one's interest, although it is not sure that they are identical with the neurofilaments.

Especially noteworthy is the presence of a bundle of banded fibrils enveloped by the Golgi complex. Its periodicity is generally common to the rootlets of cilia or flagella of other tissues of Amphioxus. Thus the existence of the intracellular banded fibril and of the flagellum in the intracellular cavity between the pigment cell and the visual cell strongly suggests that the visual cell is flagellated and lends support to the idea of the ependymal origin of this visual cell, although the photoreceptoral structure is not the derivative of the flagellum. The pigment cell is also suggested to be ciliated on the luminal side, not on the visual cell side. Therefore, the flagellum found in the intercelullar cavity between the visual cell and the pigment cell seems to belong more likely to the former rather than to the latter.

In mollusks the cephalopods often contain axial filaments in the axes of the rod-shaped visual cell ${ }^{12}$. In the electron microscope investigation of the proximal retina of Pecton ${ }^{1)}$, the axial filament has been seen with a banded appearance in the sense cell which possesses the rhabdomere as photoreceptoral structure. Moreover, it has been proved that the distal sense cell appendage of Pecten is composed of concentric lamellae, each of which is continuous with a ciliary stalk and basal $\operatorname{body}^{32)}$.

The existence of abundant glycogen granules in the basal part of the cell makes a feature of the visual cell of the Becheraugen to distinguish it from the cone of the vertebrate lateral eye, in which glycogen is proved in the paraboloid ${ }^{33)}$. The paraboloid is usually a solid or semi-solid body distal or apical to the nucleus, which is just the reverse of the Becheraugen. Rods may have paraboloids, but only when they have had a particular history ${ }^{34}$. 
Furthermore, the fact that in the ependymal cells the glycogen granules are present preferentially in its basal part affords an another support to the idea of the ependymal origin of this visual cell.

The aggregation of mitochondria adjacent to the tubular zone of the Becheraugen and in the distal part of the ependymal sense cell is of interest, comparing to the mitochondrial aggregation in the ellipsoid of the vertebrate lateral eye.

\section{Dorsal cell}

Eakin and Westfall ${ }^{17}$ ) reported that the dorsal cell is strikingly similar in fine structures to the visual cell of the Becheraugen and possesses the labyrinth of tubules which are formed by the infoldings of the surface membrane of the cell. Further, they added that they are probably lightsensitive.

As has been described in the present study, the dorsal cell possesses prominent structures some of which are inconsistent with the information of Eakin and Westfall. Its fine structure suggests that it may act as a secretory cell on the one hand.

\section{Ependymal sense cell}

Satir, as reported by Miller ${ }^{1)}$, found cells near the infundibular organ which are similar to the vertebrate visual cells and the distal sense cells in the retina of Pecten $^{32}$ ) in that they have appendages of lamellar structures which are ciliary derivatives.

The ependymal sense cell described in the present study is supposed to be identical with that found by Satir.

Although whether or not the ependymal sense cells are functional as a photoreceptoral organ is a controversial subject, the following remarks strongly suggest their close relationship to the sense cells of the pineal complex of some vertebrates. Their location at the level of the infundibular organ which is regarded to be homologous with that of the vertebrates ${ }^{35,36)}$, interposed among ependymal cells, in the roof or dorsal wall of the ventricular cavity in the neural tube supplies a firm basis for this idea.

Developmental analyses of these organs afford a further support to this idea. For example, the parietal eye develops as a vesicle from the roof of the neural tube in close association with the epiphysial evagination. The embryonic outpocketing is lined with ependymal cells. After the parietal vesicle becomes separated from the epiphysis, the retina of the parietal eye which corresponds not with that of the lateral eye but with its pigment epithelium, develops from the ventrolateral wall of the vesicle with the cilia of the prospective retinal cells projecting into the lumen of the eye, because there is no invagination of the vesicle to form a cup, as in the development of the lateral eye $\mathrm{e}^{37-39)}$.

From these respects it becomes more reasonable to speculate that the 
ependymal sense cell of Amphioxus and the sense cells of the pineal complex of some vertebrates ${ }^{19-28}$ ) have common features of a general sort.

Furthermore, the high degree of their similarity to the lateral eyes of the vertebrates ${ }^{1,40}$ ) is striking and lends an additional support of the theory of the ependymal origin of photoreceptors ${ }^{41,42}$ ).

Electrophysiologically the frontal organ and the parietal eye of the pineal complex of some vertebrates have been proved to be photosensitive organs ${ }^{\mathbf{4 3}, 44}$. Another evidence as significant reduction in the glycogen content of the pineal organs and of the parietal eyes upon light adaptation lends further support to the idea ${ }^{20,22)}$.

Various investigators have considered the frontal and pineal organs to be secretor ${ }^{45,46)}$. The other earlier worker has thought that the amphibian pineal organs were involved in the control of pigmentation, especially in anuran larvae. ${ }^{47}$ ) More recently some investigations ${ }^{48-50}$ ) have been made in this respect, but it appears that much more work is needed to clarify the effects of pineal activity upon the pigmentary system.

Are there any keys to see in what respects the ependymal sense cells resemble either the rod or cone of the lateral eye? Eakin and Westfall ${ }^{20}$ ) made interesting examinations on the parietal eye of the lizard, suggesting its possible relationship to the cone of the lateral eye. More recently Brown, Gibbons and Wald ${ }^{40}$ ) observed several structural features to discern the rod and cone in the visual cells of the mudpuppy. The present study has no significant available data on the ependymal sense cell of Amphioxus in this respect.

\section{Infundibular organ}

The so-called infundibular organ of Amphioxus is found in the ventral wall of the neural tube at the level a little cranial to the caudal end of the ventricular cavity. Eakin and Westfall ${ }^{17}$ ) observed the vesicles in the filaments and cilia on the ventral surface of the posterior part of the cerebral vesicle and, assuming these vesicles-containing filaments and cilia to belong to the cells of the infundibular organ, speculated that they might be suggestive of the origin of the vertebrate photoreceptors.

The structural feature of the cells of the infundibular organ is not consistent with those which have been found in the photoreceptor of other animals, but their general feature strongly suggests them to be secretory in their functional properties (Fig. 16).

The cell is elongated and ciliated bearing a pair of basal bodies with banded rootlets and contains numerous granules, bounded by a membrane, with contents of fine granular materials. This cell has a deep periflagellar recess, at the luminal end, which is observed to be filled with fine granular material which is identical with the content of the intracellular granules (Fig. 16). 
For these reasons, the granules are supposed to be secreted into the periflagellar recess and then into the ventricular cavity along the flagellum. The oval nucleus is located in the basal part of the cell. Numerous agranular vesicles, the well-developed Golgi complex, and the granular endoplasmic reticulum are seen.

\section{CONCLUSION}

1. The visual cell of the Becheraugen has the Stiftchensaum on its cell surface adjacent to the pigment cell. The Stiftchensaum is composed of numerous microvilli with their long axes oriented normal to the cell contour. Just inside the Stiftchensaum is the zone of tubular compartments, the long axes of which are also perpendicularly oriented to the visual cell surface. Adjacent to the tubular zone are observed clumps of tightly packed mitochondria. The existence of a banded axial fibril enveloped by well-developed Golgi complex and of a flagellum in the intercellular cavity strongly suggests that the visual cell of the Becheraugen is flagellated. The basal part of the cell is mostly occupied by abundant glycogen granules.

2. The dorsal cell has the Stiftchensaum similar to that of the Becheraugen but lacks the cap of the pigment cell. The most prominent feature of the cytoplasm is the abundance of vesicles of variable size with variable contents. The general feature suggests that its functional property is secretion as well as photosensation.

3. The ependymal sense cell of Amphioxus is supposed to be identical with the sense cell of the pineal complex of some vertebrates from its high degree of similarity in their position in the neural tube and in fine structure.

4. The infundibular organ is shown to be secretory in its functional property.

\section{Acknowledgment}

The author most gratefully expresses his sincere thanks to Dr. Ryoji Ura, Professor of Anatomy, Tohoku University School of Medicine, for his encouragement in pursuing this research. To Dr. Takeo Osaki, Professor of Anatomy, Fukushima Medical College, and Dr. Atsushi Ichikawa, Assistant Professor of Anatomy, Tohoku University School of Medicine, the author also extends his deep thanks and an appreciation for their guidance in learning the techniques of electron microscopy and for many valuable discussions in ultrastructural analyses.

\section{References}

1) Miller, W.H., The Cell, 1960, IV Part 1, New York \& London, Academic Press.

2) Franz, V., Lehrb. d. vergl. mikrosk. Anat. d. Wirbeltiere, 1913, VII, 1.

3) Joseph, H., Verh. anat. Ges., 1904, 18. (cited from 2).

4) Hesse, R., Z. wiss. Zool., 1898, 63, 456.

5) Caulfield, J.B., J. biophys. biochem. Cytol., 1957, 3, 827.

6) Luft, J.H., J. biophys. biochem. Cytol., 1961, 9, 409. 
7) Reynolds, E.S., J. Cell. Biol., 1963, 17, 208.

8) Yamamoto, T., Acta Anat. Nippon., 1963, 38, 124.

9) Franz, V., Ergebn. Anat. Entwickl.-Gesch., 1927, 27, 464.

10) Lönnberg, G.F., Bronn's Klass. u. Ordn. d. Thier-Reichs, 1924, 99.

11) Yamada, H., unpublished.

12) Hesse, R., Z. wiss. Zool., 1900, 68, 379.

13) Boeke, J., Kon. Akad. Wetensch. Amsterdam., 1902, (cited from 2).

14) Revel, J.P., Napolitano, L. \& Fawcett, D.W., J. biophys. biochem. Cytol., 1960, 8, 575.

15) Drochmans, P., J., Ultrastruct. Res., 1962, 6, 141.

16) De Robertis, E., Int. Rev. Cytol., 1959, VIII, 61.

17) Eakin, R.M. \& Westfall, J.A., J. Ultrastruct. Res., 1962, 6, 531.

18) Edinger, L., Anat. Anz., 1906, 28, 417.

19) Eakin, R.M. \& Westfall, J.A., J. biophys. biochem. Cytol., 1959, 6, 133.

20) Eakin, R.M. \& Westfall, J.A., J. biophys. biochem. Cytol., 1960, 8, 483.

21) Eakin, R.M., Quay, W.B. \& Westfall, J.A., Z. Zellforsch., 1961, 53, 449.

22) Eakin, R.M., Quay, W.B. \& Westfall, J.A., Z. Zellforsch., 1963, 59, 663.

23) Oksche, A. \& Harneck, M.V., Naturwissenschaften, 1962, 49, 429.

24) Oksche, A. \& Harneck, M.V., Z. Zellforsch., 1963, 59, 239.

25) Oksche, A. \& Harneck, M.V., Z. Zellforsch., 1963, 59, 582.

26) Oksche, A., Z. Zellforsch., 1962, 57, 240.

27) Steyn, W., Nature, 1959, 183, 764.

28) Steyn, W., Z. Zellforsch., 1960, 51, 735.

29) Dowling, J.E. \& Gibbons, I.R., The Structure of the Eye, 1961, 85. (cited from 40).

30) De Robertis, E. \& Lasansky, A., The Structure of the Eye, 1961, 29. (cited from 40).

31) Miller, W.H., J. biophys. biochem. Cytol., 1957, 3, 421.

32) Miller, W.H., J. biophys. biochem. Cytol., 1958, 4, 227.

33) Sidman, R.L. \& Wislocki, G.B., J. Histochem. Cytochem., 1954, 2, 413.

34) Walls, G.L., The vertebrate Eye and Its Adaptive Radiation, Bloomfiled. Hills, Michgan, Cranbrook Institute of Science, 1942, cited from 20).

35) Boeke, J., Anat. Anz., 1902, 21, 411.

36) Boeke, J., Anat. Anz., 1908, 33, 273.

37) Nowikoff, M., Z. wiss. Zool., 1910, 96.

38) Steyn, W., J. comp. Neurol., 1957, 107, 227.

39) Trost, E., Z. Zellforsch., 1953, 38, 185.

40) Brown, P.K., Gibbons, I.R. \& Wald, G., J. Cell Biol., 1963, 19, 79.

41) Walls, G.L., Arch. Ophthal. 1939, 22, 452.

42) Walls, G.L., Biol. Symp., 1942, 7, 203.

43) Dodt, E. \& Heerd, E., J. Neurophysiol., 1962, 25, 405.

44) Miller, W.H. \& Wolbarsht, M.L., Science, 1962, 135, 316.

45) Oksche, A., Morph. Jb., 1952, 92, 123.

46) Kelly, D.E. \& van de Kamer, J.C., Z. Zellforsch., 1960, 52, 618.

47) Fuchs, R.F., Handbuch. d. vergl. Physiol., 1914, 3, 1189. (cited form 22).

48) Bagnara, J.T., Science, 1960, 132, 1481.

49) Brick, I., Anat. Rec., 1962, 142, 299.

50) Kelly, D.E., Z. Zellforsch., 1963, 58, 693.

51) Fernández-Morán, H., Nature, 1956, 177, 742.

52) Fernández-Morán, H., Exp. Cell. Res., 1958, 15, Suppl. 5, 586.

53) Miller, W.H., J. biophys. biochem. Cytol., 1957, 3, 421.

54) Miller, W.H., Science, 1957, 126, 1233.

55) Miller, W.H., J. biophys. biochem. Cytol., 1958, 4, 227.

56) Goldsmith, T.H. \& Philpott, D.E., J. biophys. biochem. Cytol., 1957, 3, 441. 


\section{EXPLANATION OF FIGURES}

\section{Key to Abbreviations}

C, centrioles. D, desmosomes. EF, ependymal fibers. ER, endoplasmic reticulum. f, filaments. F, banded axial fibril. Fil, neurofilaments? Fl, flagellum. G, Golgi complex. Gl, glycogen granules. I, inclusion bodies. M, mitochondria. N, neurite. $\mathrm{P}$, pigment cell. $\mathrm{R}$, banded rootlets. RNP, ribonucleoprotein granules. $\mathbf{r - E R}$, roughsurfaced or granular endoplasmic reticulum. S, Stiftchensaum. s-ER, smooth-surfaced or agranular endoplasmic reticulum. T, tubular zone.

Fig. 1 and 2. Serial sections of a Becherauge. Note that the tubular zone $(\mathrm{T})$ is closely associated with the Stiftchensaum (S) and that a banded axial fibril (F) is enveloped by a well-developed Golgi complex (C). Magnification 9,000 $\times$.

Fig. 3. Stiftchensaum is clearly shown to be composed of microvilli of the visual cell (arrow). Note that tubular compartments of the tubular zone are continuous with the adjacent well-developed ER which bears some RNP granules at certain places. Magnification 22,680 $\times$.

Fig. 4. Basal part of the visual cell. Note that the peripheral part of the Stiftchensaum which is composed of rod-like microvilli is closely associated with the well-developed tubular zone, and that a neurite is fully occupied by numerous dense granules (glycogen granules, c.f. Fig. 12). Magnification 18,000 $\times$.

Fig. 5. Basal part of the visual cell. Note that mitochondria (M) are interposed among well-developed endoplasmic reticulum (ER) which bears RNP granules (RNP 1) at certain places, and that a number of small aggregations of glycogen and free RNP granules (RNP 2) occupies the basal part of the cell. Magnification 21,600 $\times$.

Fig. $6 \mathrm{a}$ and $6 \mathrm{~b}$. Serial sections of two Becheraugen in close contact. Note that individual cells ( 1 and 2) possess their own pigment cells (PI and 2). Fig. 6a shows a cross section of tubular compartments of the well-developed tubular zone, and Fig. $6 \mathrm{~b}$ does a longitudinal section of the tubular compartments. Magnification 11,200 $\times$.

Fig. 7. Encapsuled together by ependymal fibers, a synapsis with the visual cell is shown. Magnification $18,800 \times$.

Fig. 8. A pigment cell of Becherauge borders the central canal interposed among the ependymal cells. This fact indicates that the pigment cells of the Becheraugen are the direct derivatives of the ependyaml cells or modified ependymal cells. Magnification $5,440 \times$.

Fig. 9. Peripheral part of the Stiftchensaum. Note a flagellum in the intercellular space between the visual cell and the pigment cell. Magnification 12,000 $\times$.

Fig. 10. Schema represents the relationships of the tubular compartments of the tubular zone to the Stiftchensaum, the endoplasmic reticulum and RNP granules.

Fig. 11. A part of the dorsal cell in which a banded fibirl is shown to extend to the Stiftchensaum. Magnification $15,200 \times$.

Fig. 12. Tangential section to the dorsal cell surface. Note a flagellum in the maze of the Stiftchensaum. The fine structure of the flagellum provides the evidence that this maze is formed by projections of the dorsal cell surface, as mentioned previously in the text. Magnification $14,480 \times$.

Fig. 13. Stiftchensaum of the dorsal cell cut through a plane of section normal to the cell surface. Some of projections which form the Stiftchensaum are shown to contain uniformly sized tubules. Magnification 15,040 $\times$. 
Fig. 14. Ependymal sense cells. Note that most of mitochondria are found in the apical part of the cell and that the basal part of a sense cell is occupied by abundant glycogen granules. Magnification 4,300 $\times$.

Fig. 15. In the lamellar structure of the ependymal sense cells linear arrangements of vesicles are notable. Note that these vesicles seem to be formed by fusion of single membranes of adjacent sacs or discs, and that interspaces between them are apparently extracellular spaces. The interior of the sac or the intermediate layer of the disc contains microvesicular bodies. Magnification 26,080 $\times$.

Fig. 16. Infundibular organ. In this figure the process of secretion of the intracellular grnaules into the periflagellar recess and then into the ventricular cavity are supposed to take place following the stages of 1 to 9 in the order of assumed sequence. Magnification $9,120 \times$. 


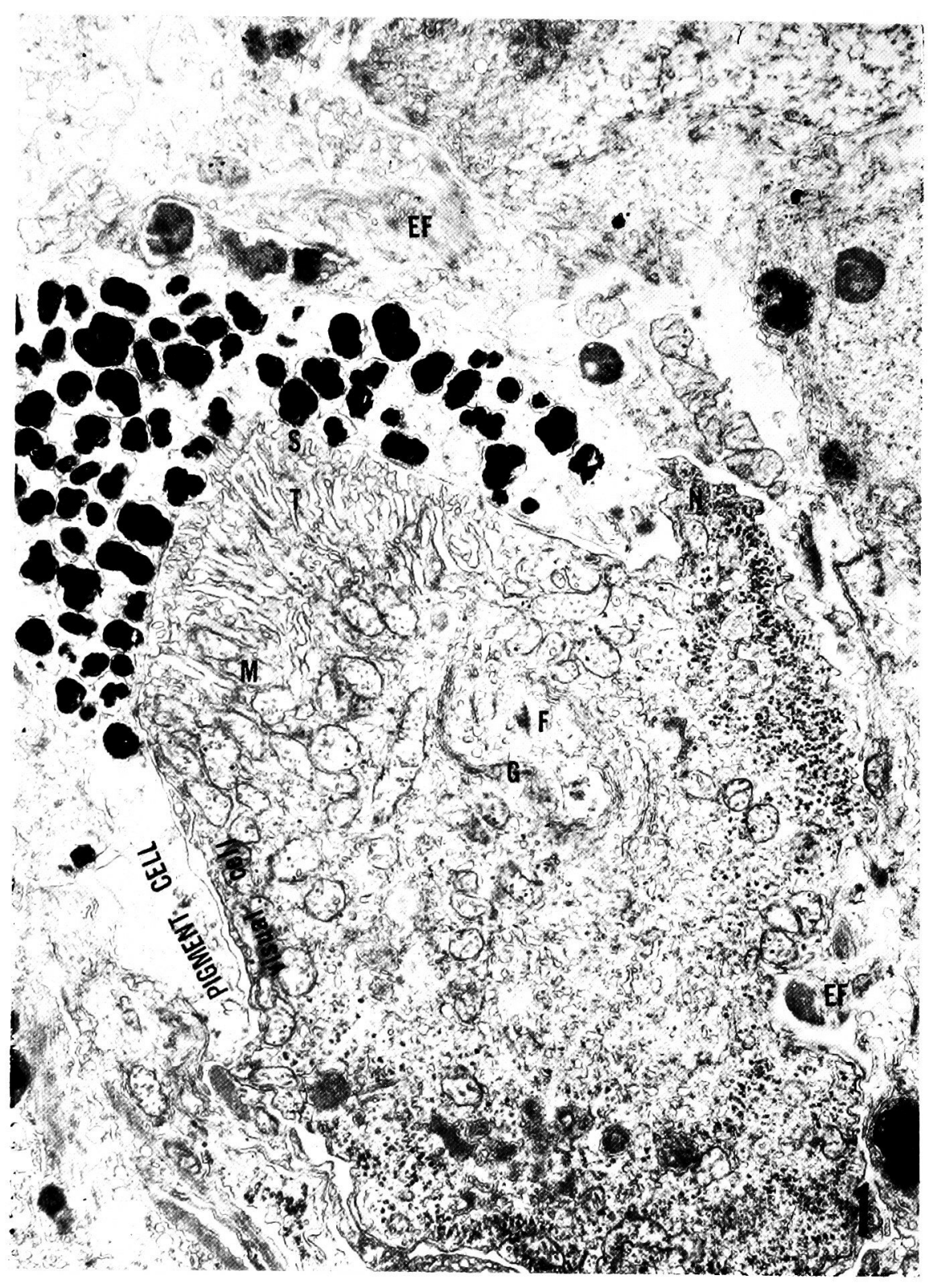




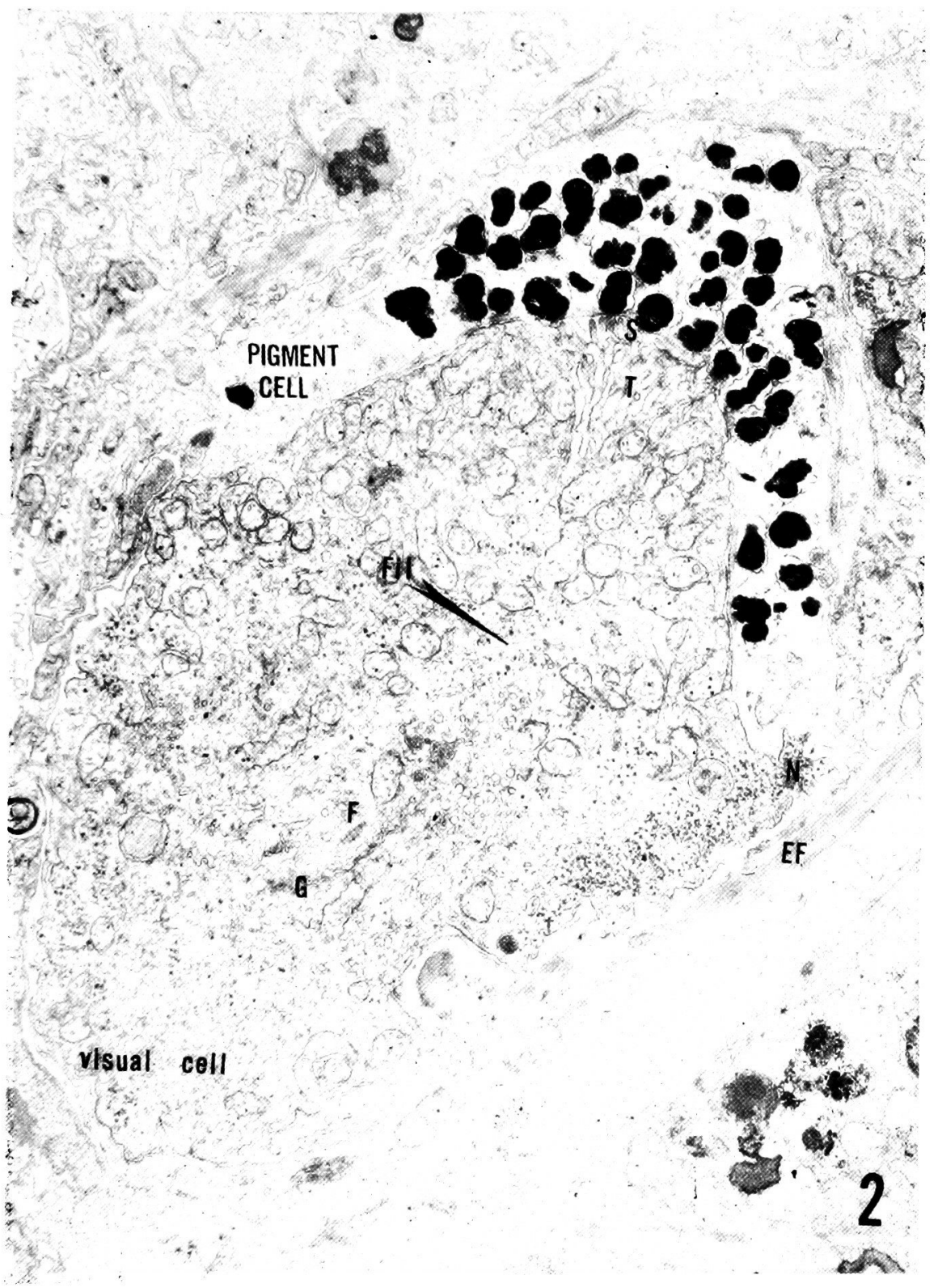




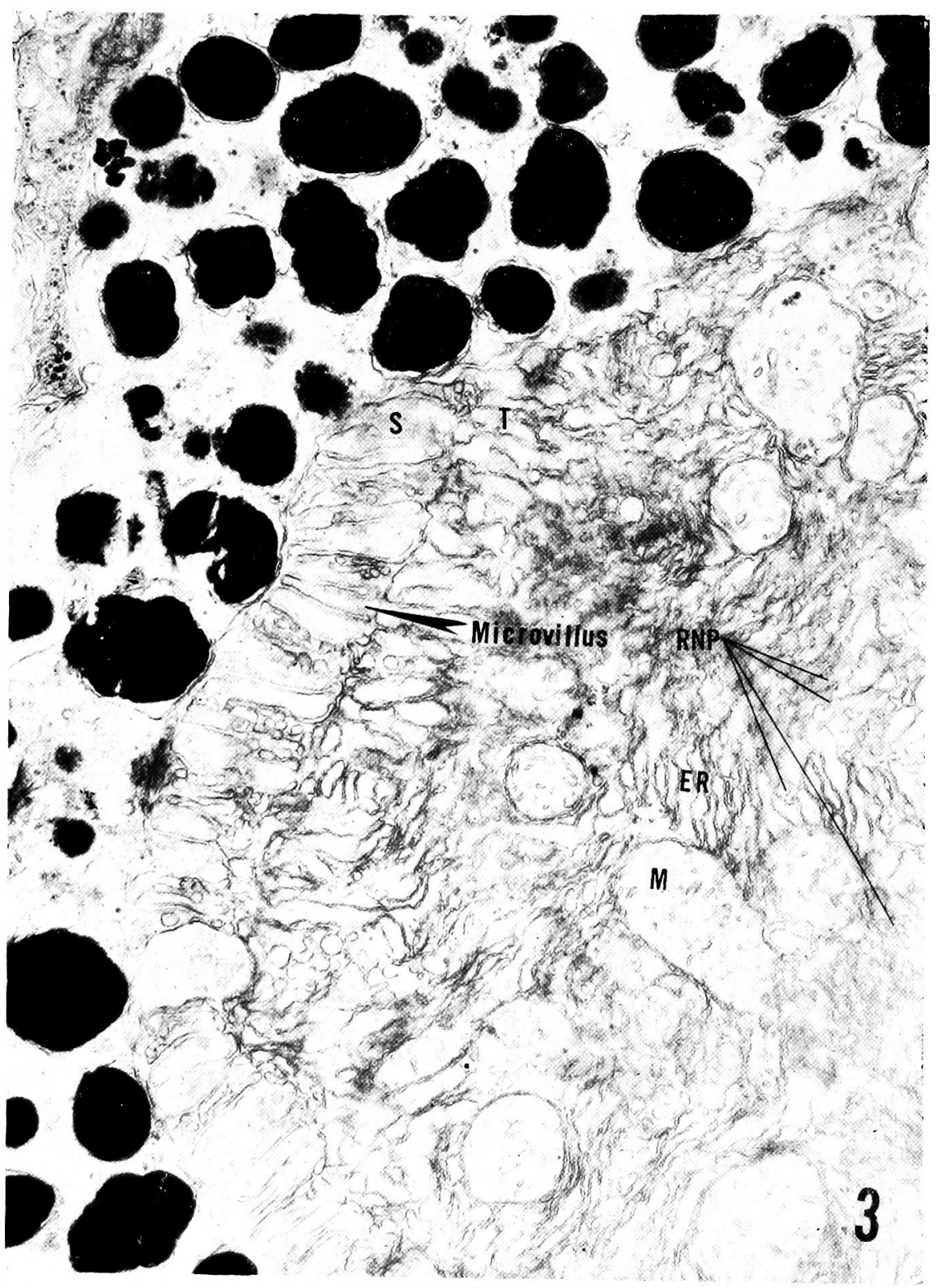




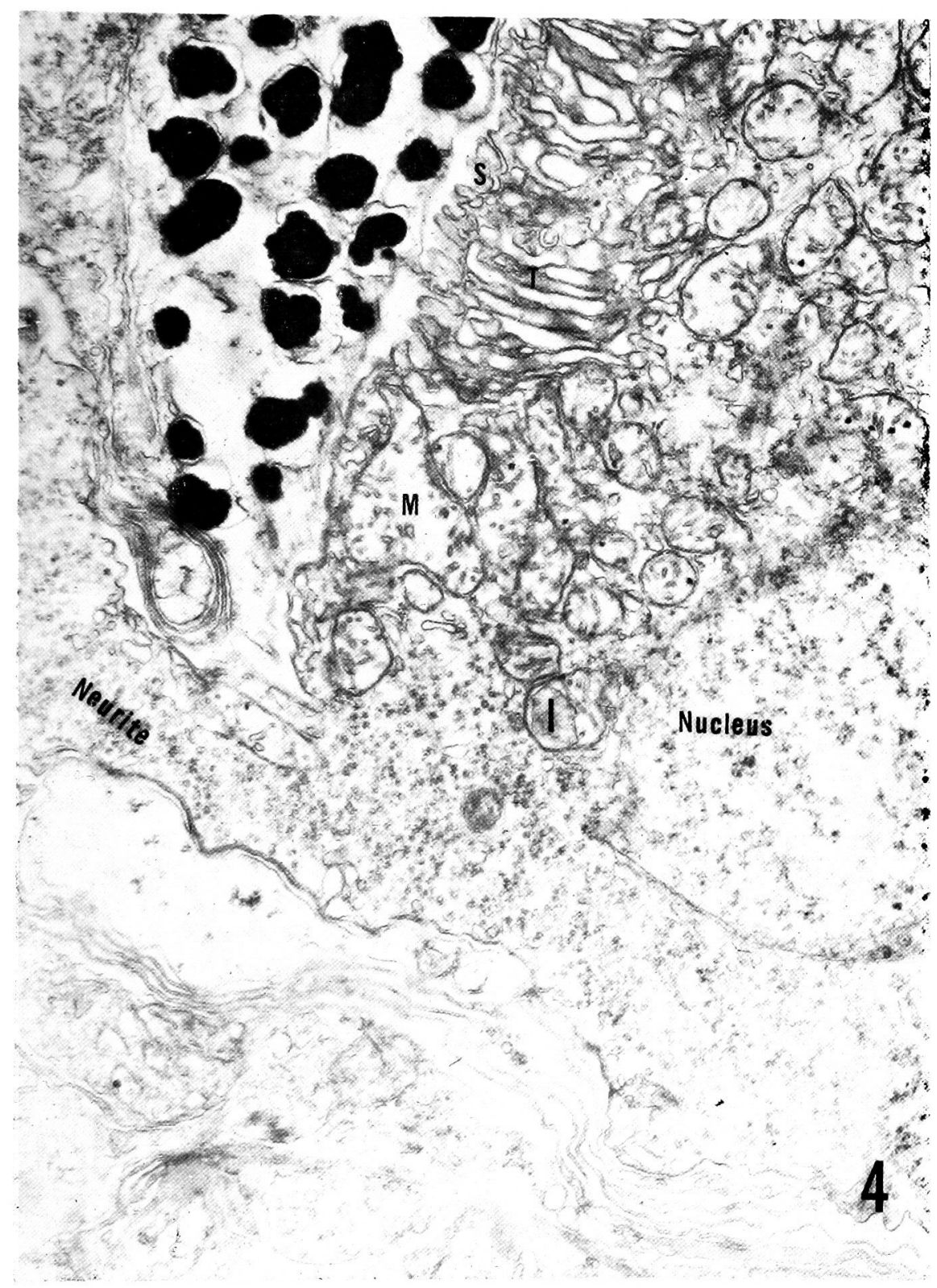









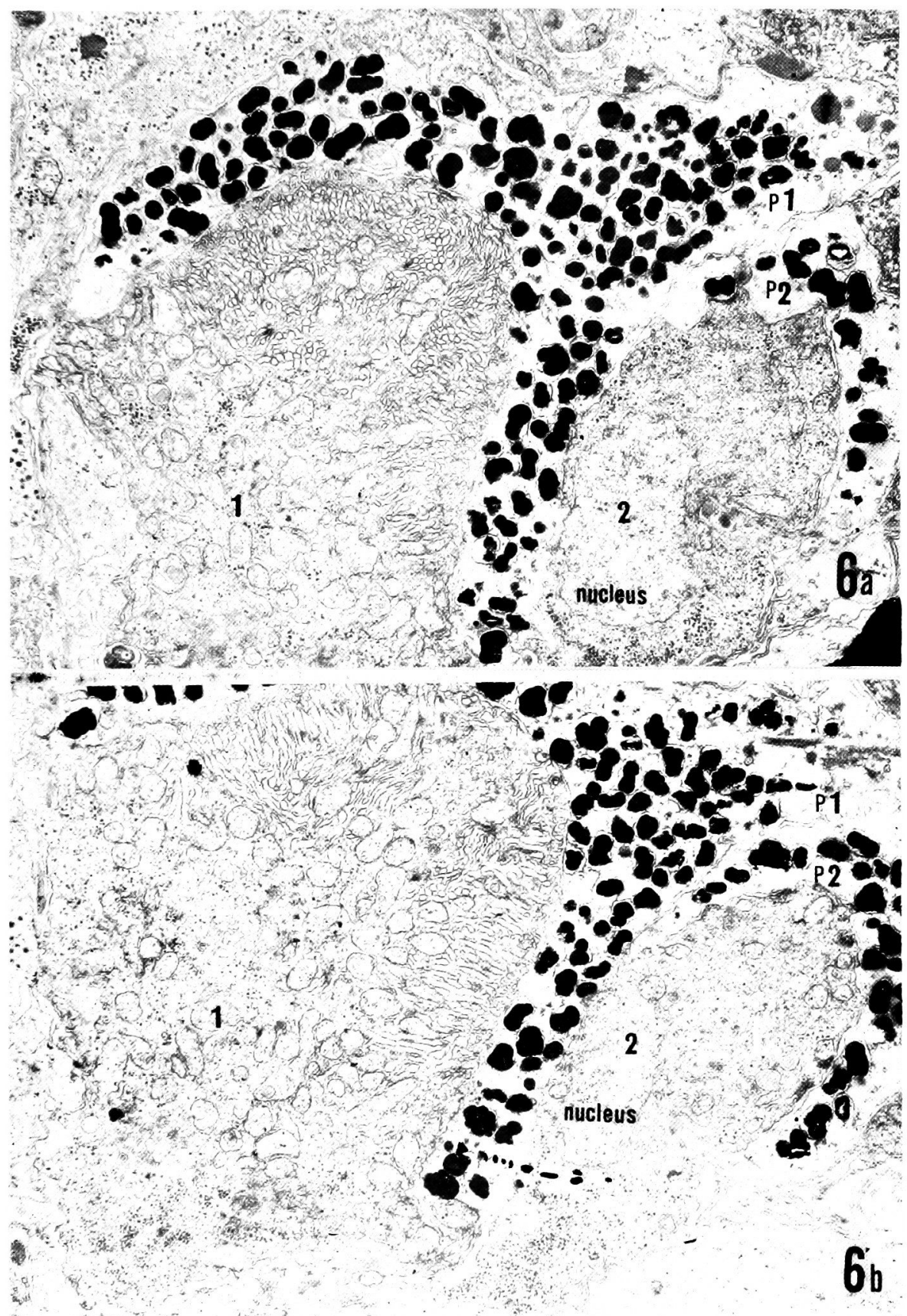




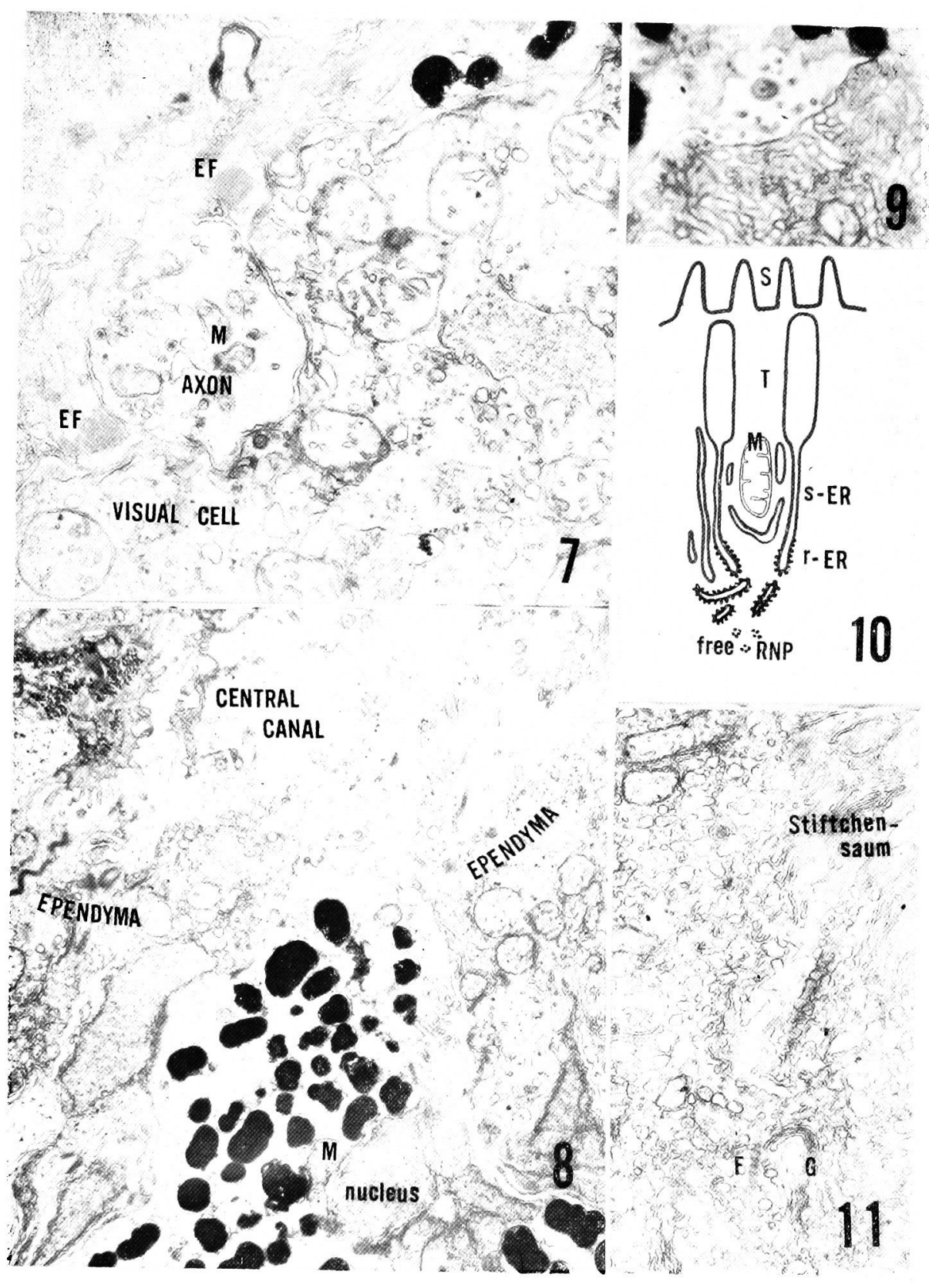




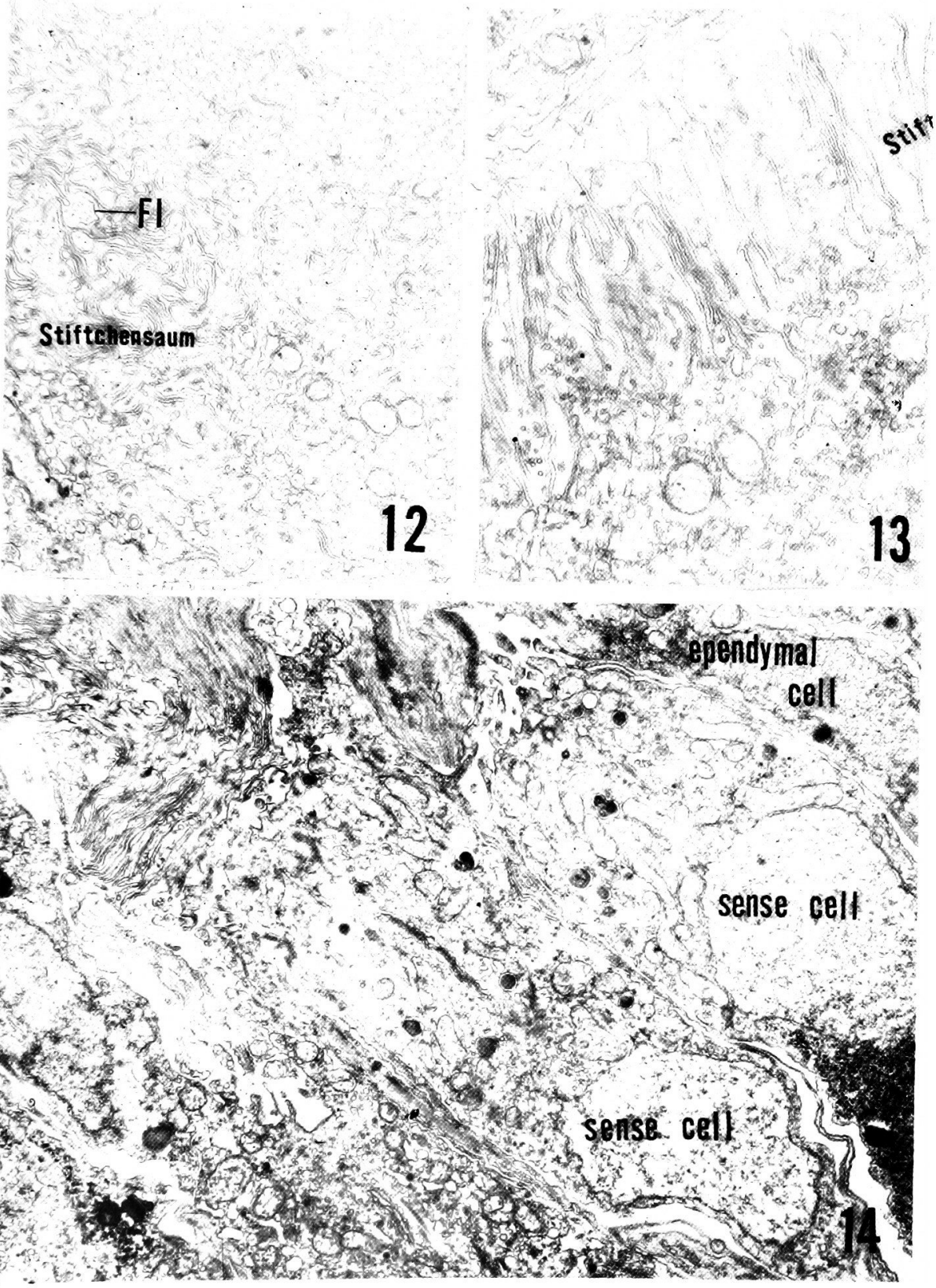



